\title{
Competency improvement of cooperative managers to improve members' welfare by implementing business strategies
}

\author{
Agus Haryono $^{a}$, Mudjiarto ${ }^{a}$, Nanik Wahyuni ${ }^{b *}$ and Boge Triatmanto ${ }^{a}$ \\ ${ }^{a}$ Faculty of Economic, University of Merdeka Malang, Indonesia \\ ${ }^{b}$ Faculty of Economics, Universitas Islam Negeri Maulana malik Ibrahim, Malang, Indonesia

\begin{tabular}{|c|c|}
\hline CHRON I C L E & A B S T RACT \\
\hline $\begin{array}{l}\text { Article history: } \\
\text { Received: June } 20,2020 \\
\text { Received in revised format: } \\
\text { August } 302020 \\
\text { Accepted: September } 29,2020 \\
\text { Available online: } \\
\text { September } 29,2020 \\
\text { Keywords: } \\
\text { Women's Cooperative } \\
\text { Member welfare } \\
\text { Competence } \\
\text { Business strategy }\end{array}$ & $\begin{array}{l}\text { This study aims to analyze the improvement of the welfare of cooperative members in a sustainable } \\
\text { manner, which is influenced by the development of business strategies and the competence of } \\
\text { members. The research was conducted at women's cooperatives in East Java Province, Indonesia. } \\
\text { The research design uses a quantitative approach. Respondents in this study are members of active } \\
\text { women's cooperatives who have their own businesses from cooperative capital. The questionnaire } \\
\text { was distributed by directly meeting respondents or via email among } 185 \text { respondents who were } \\
\text { members of active cooperatives. SEM analysis was used to determine the effect of competency } \\
\text { variables on improving member welfare mediated by business strategies. The results of this study } \\
\text { indicate that the welfare of cooperative members was largely determined by the competence of } \\
\text { cooperative member business actors, but this welfare improvement will be more effective if } \\
\text { business actors understand and implement business strategies even though on a small scale. }\end{array}$ \\
\hline
\end{tabular}

C 2021 by the authors; licensee Growing Science, Canada

\section{Introduction}

Until now, cooperatives in Indonesia are still dependent on the helping hand of the government. However, if data collection is carried out carefully, less than a third of the existing cooperatives have received a helping hand from the government or have become part of government programs. This means that there is a great desire to cooperate in the midst of their economic limitations. This indicates that community participation in cooperatives still plays a real role in economic life in Indonesia. However, people's desire to cooperate has grown slowly. Although the number of newly established cooperatives continues to increase, community participation in cooperative membership is still relatively low (Mubarok et al., 2019; Syaiful, 2016). The relationship between community membership in cooperatives and their economic role is evident in practice, specilly in the West and also in Indonesia. However, the Indonesian cooperative is less significant in economic role since less than a fifth of Indonesia's population is a member of the cooperative. Now the activities of Indonesian cooperatives are already in various economic sectors, but the dominance of cooperative business strength is still grouped in savings and loan activities (Mubarok et al., 2019). Community participation in cooperative membership moves between $10 \%$ and $15 \%$ of the population, both over time and across regions. The contribution of cooperatives to economic growth is still relatively low compared to other economic sectors (Bijaoui \& Regev, 2015). The most considerable contribution to economic growth in East Java is dominated by the manufacturing industry and other service industries. This causes economic growth to be unable to provide a trickling down effect that can push the local economy to a lower level. This relates to production factors, markets, and the competence of local economic actors to enter the mass production process chain and connect to large industries (Finlayson et al., 2018). Optimizing economic improvement through increasing the welfare of cooperative members, it is necessary to conduct in-

* Corresponding author.

E-mail address: nanik@akuntansi.uin-malang.ac.id (N. Wahyuni) 
depth studies with intensive research (Wahid et al., 2013). This research was conducted to find a model for improving the welfare of cooperative members through increasing competence and changing business strategies. We consider that in order to provide optimal results in increasing the chain of production, marketing, and developing cooperatives and their members, the competency development of the management and members of the cooperative is the primary social capital. This study aims to improve the welfare of cooperatives and their members in East Java Province by increasing competence and determining the correct business strategy so that cooperatives and cooperative members are able to compete and develop, both in terms of efficiency of production processes, capital, marketing networks compared to other economic actors.

The virtue of this research is to create a model for increasing the welfare of members that is more in line with the characteristics of the local community and culture and is planned in an integrated manner by taking into account the potential of local resources, starting from the institutional structure that is able to synergize between economic actors built-in local economic improvement programs through synergy. Three pillars of research and development are academics, government, and business actors to network with stakeholders and other caring groups. This research aims to investigate the increase in the welfare of cooperative members, which is mediated by the business strategy by increasing the competence of cooperative members' training.

\section{Literature review}

\subsection{Competence}

Competence is the ability to do something that is obtained through education and training (Avkiran, 2000; Polnaya et al., 2018). Competence is an attempt to describe what is expected, desired, coveted, anticipated, managed, and so on. Competence describes the behaviors associated with desired performances and also describes the work context (Hampton et al., 2009). In defining competence, competence must: (1) have complex performance, (2) be useful, described by services and products, (3) reality-oriented, (4) can be predicted for the present and future, (5) has a high priority among performance expectations, and (6) explain performance patterns (Conway, 1994; Decius \& Schaper, 2017; Kunjiapu \& Mohamad, 2010). Based on the above definitions, it can be concluded that competence is a set of behaviors that contain a distinctive pattern of appearance that describes the implementation of relevant tasks. Professional competence can be defined as a summary of the key professional and personal skills and talents, and patterns of behavior that an individual must possess and demonstrate in order to successfully achieve defined professional goals and perform related professional tasks, duties, and responsibilities (Blašková et al., 2014). Competence is defined as a proven ability to use knowledge and skills (Glogger-frey et al., 2017; Moghabghab et al., 2016). This is also explained in terms of responsibility and autonomy. A different view can be applied to what is known as general human competence, which, to some extent, reflects all human endeavors in an organization (An \& Han, 2020; Ataei et al., 2020).

\subsection{Business Strategy}

Competition intensity is rooted in three types of the competitive environment, namely: perfect competition, pure monopoly, and imperfect competition (Boso et al., 2012; Hallbäck \& Gabrielsson, 2013). A perfectly competitive market is characterized by the following conditions: 1). There is no product differentiation; 2). Same company knowledge; 3 ). Not an entry barrier; 4). Not hurdle exit 5). Competition is atomic (Iglesias et al., 2019; Waweru, Nelson; Uliana, 2008). Whereas in a monopoly market, there is no competition since there is only a single seller and products that are sold are unique, there are no substitutes for goods, and if the buyer wants to buy a product, the buyer must buy from a single seller. Very fierce competition occurs both in perfect competition and monopolistic markets, in imperfect competition and monopolistic markets, there are a lot of companies operating, which may result in intense competition, and to win this competition, a superior competitive strategy is needed. The typology of strategies developed includes prospectors, defenders, analyzers, and reactors (Iglesias et al., 2019; Kouropalatis et al., 2012; Lytle \& Timmerman, 2006). Meanwhile, Porter (1980) proposes two different types of strategies, namely the low-cost strategy and product differentiation strategy (Cuganesan et al., 2012; Linton \& Kask, 2017).

\subsection{The Concept of Welfare}

The level of welfare is a concept used to express the quality of life of a community or individual in an area at a certain time (Abu Talib et al., 2018; Engineer, Merwan, \& Ian King, 2008). The concept of welfare that is owned is relative, depending on how each individual assesses the welfare itself. Prosperity for someone with a certain level of income cannot be said to be prosperous for others (Syaiful, 2016). Welfare is a condition in which all the physical and spiritual needs of the household can be met according to the level of life (BPS, 2018). The dimensions of people's welfare are realized to be very broad and complicated so that a level of people's welfare can only be seen through a particular aspect (Mubarok et al., 2019; Tremblay et al., 2019). Therefore, people's welfare can be observed in various specific elements. 


\section{Method}

The design of this study is quantitative to analyze the increase in welfare, which is influenced by competence and mediated by business strategies. The method of analysis uses SEM analysis to determine the influence between the variables studied so that it is expected to be part of the decision making for cooperative programs and activities. The population in this study included the management and members of women's cooperatives in East Java Province, namely 185 active members of the cooperative. The sampling technique used purposive sampling to facilitate intervention in developing cooperative competence and its members in making changes to their business strategies. In addition, documentation techniques are used to suit the needs of the analysis.

\section{Result}

The results of the calculation of the unidimensionality construct of the member's welfare construct have met the requirements for confirmatory factor analysis. The GFI value as a measure of the feasibility of the model reaches a value of 0.937 (greater than 0.90) and a Chi-square value of 19.536. Based on this, it can be concluded that there is an evidence that the welfare construct has an acceptable unidimensionality. The test results on the C.R statistic on each indicator on the construct of member's welfare have shown significant results. This result is evidenced by a C.R value of more than two or a $\mathrm{p}$-value $<0.05$. Based on the loading value (lambda), all values are above 0.30 , so that it also provides evidence that each indicator has a high level of construct validity. Substantially, the dimensionality test results show that the dimensions can construct the welfare of members. The highest loading value is found in the dimension of the family health level. This largest loading means that the respondents in this study have the right level of family health after becoming members of the cooperative. The results of this analysis also explain that there is a large variation in the indicators of other welfare variables, namely the condition of housing facilities, the level of children's education, and the level of family income after becoming a member of the cooperative. In the other three dimensions with loading of more than 0.30 . The results of the unidimensional analysis of business strategy variables have met the requirements for confirmatory factor analysis. Substantially, the dimensionality test of the business strategy variable can be formed by three indicators. The highest loading value is an indicator of service change with the same value, amounting to 0.73 . This shows that so far, cooperative member business actors have provided reasonably good service to consumers. The two other indicators with loading more than 0.30 can also explain that the implementation of business strategies can be measured through product changes and changes in the right distribution channel. The results of the unidimensionality analysis of the competency improvement variable have met the requirements for confirmatory factor analysis. Substantially, the dimensionality test of the competency improvement variable can be formed by four indicators. The highest loading value is an indicator of experience with a value of 0.84 . This shows that according to the perception of respondents, namely members of female cooperatives that increased competence in running a business as a member of a cooperative, where the working capital is from the cooperative. Besides that, increasing creativity is the second important indicator. These two indicators are essential to improve the competence of cooperative member business actors. In the other three dimensions with loading of more than 0.30 , it can also be explained that the increase in the competence of cooperative member business actors can be measured through the right business motivation, adequate experience, and relatively stable emotional abilities.

\subsection{Structural Equation Model}

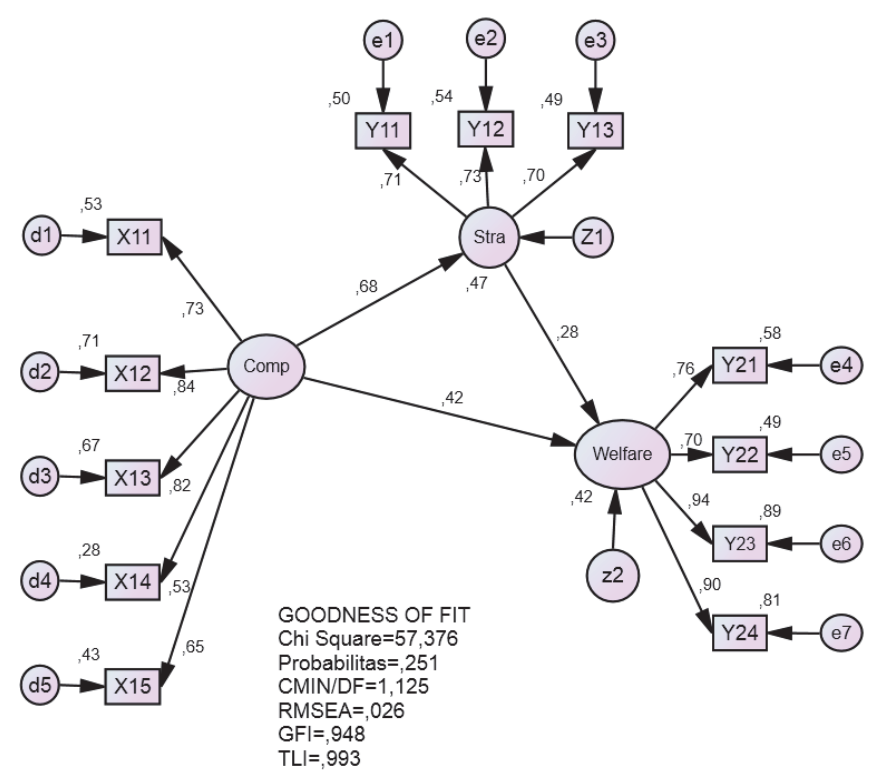

Fig. 1. Final Research Model 
After the latent variables have been tested to form unidimensionality and meet the SEM assumptions, the next step is to evaluate the structural equation model by comparing the index of fit value with the cut-off value criteria of the structural equation model. The results of the structural equation model testing prove that the probability value has met the recommended one, while the other values Chi-Square, CMIN / DF, RMSEA are categorized as moderate, while the GFI and TLI values are categorized as satisfying. Hair et al. (1995) explained that the model is declared good if the Chi-Square and Probability values meet the recommended cut-off values. Thus, the structural equation model that is built can be used as an analysis tool and test the research hypothesis.

\subsection{Loading Factor Analysis in the Structural Equation Model}

Before discussing the structural equations that are formed, first, an analysis of the factor loading of each latent exogenous and latent endogenous variable is conducted.

Table 1

Loading factor variables and research indicators

\begin{tabular}{|c|c|c|c|}
\hline Variable & Indicator & Factor Loading & Mean Indicator \\
\hline \multirow[t]{5}{*}{ Welfare } & Family income level & .76 & 3.60 \\
\hline & Family education level & .70 & 4.20 \\
\hline & Family Health Level & .94 & 4.07 \\
\hline & Condition of House Facilities & .90 & 4.02 \\
\hline & Mean Variable & & 3.86 \\
\hline \multirow[t]{4}{*}{ Business Strategy } & Product Change & 0.71 & 3.56 \\
\hline & Service Change & 0.73 & 3.57 \\
\hline & Change in Distribution & 0.70 & 3.50 \\
\hline & Mean Variable & & 3.57 \\
\hline \multirow[t]{6}{*}{ Competence } & Entrepreneurial Motivation & .73 & 3.59 \\
\hline & Experience & .84 & 3.91 \\
\hline & Creativity & .82 & 3.66 \\
\hline & Intellectual Ability & .53 & 3.92 \\
\hline & Emotional Ability & .65 & 3.73 \\
\hline & Mean Variable & & 3.65 \\
\hline
\end{tabular}

Based on Table 1, Factor loading, which explains competency variables, can be described that the experience factor dimension has a dominant contribution in explaining the competency of business actors with an estimated coefficient value of 0.84; followed by indicators of creativity; with an estimated coefficient value of 0.82 , while the entrepreneurial motivation indicator made a recessive contribution of 0.73 , respectively, the emotional ability was 0.65 , and intellectual ability was 0.53 . Factor loading, which explains the business strategy variable, can be explained that the service change dimension has a dominant contribution in defining the business strategy variable with an estimated coefficient value of 0.73 ; followed by the product change dimension with an estimated coefficient value of 0.71 , while the distribution change indicator contributed 0.70 . Factor loading that explains the variable family welfare shows that the indicator of family health has a dominant contribution in explaining the welfare variable with an estimated coefficient of 0.94 ; followed by an indicator of the condition of the house facilities with an estimated coefficient of 0.90 , then the level of family income with an estimated coefficient of 0.76 , followed by an indicator of the level of family education with an estimated coefficient of 0.70 . This research was tested by SEM analysis and fit a model to determine the causality relationship of research variables. The result of the influence test between variables is indicated by the value of the Regression Weight in the Critical Ratio column, identical to the t-count value) compared to the critical value (similar to the t-table value); The critical value for the significance level of $0.05(5 \%)$ is 1.998 (on the $t-$ table).

Table 2

The Causality Relationship of Research Variables

\begin{tabular}{|c|c|c|c|c|}
\hline & \multirow{2}{*}{ Variable } & \multicolumn{2}{|c|}{ Standardized Regression Weight } & \multirow{2}{*}{ Probability } \\
\hline & & Direct & Critical Ratio & \\
\hline Competence & $\rightarrow \quad$ Welfare & 0.329 & 5.131 & $0.000 *)$ \\
\hline Competence & $\rightarrow$ Business Strategic & 0.739 & 5.703 & $0.000 *)$ \\
\hline Business Strategic & $\rightarrow \quad$ Welfare & 0.293 & 4.042 & $0.000 *)$ \\
\hline
\end{tabular}

*) level of significant 0.05

The estimation parameter of testing the influence of competence on the welfare of members in the structural equation model shows that the CR (Critical Ratio) value of 5.703 is greater than the critical value at the significant level of 0.05 (1.998). The resulting probability value is 0.000 , less than 0.05 . So it can be concluded that the competency variable is statistically tested and has a significant effect on performance. The estimated parameter of testing the effect of competence on business strategy in the structural equation model shows that the value of $\mathrm{CR}=4.065$ is greater than the critical value of 1.998 ; The resulting 
probability value of 0.000 is smaller than 0.05 , it can be concluded that competence is statistically tested to have an effect on business strategy. Based on the results of the analysis, it can be concluded that the results of this study support the hypothesis, which states that competence has a significant and significant effect on business strategy and welfare. The estimation parameter of testing business strategy on welfare shows that the business strategy variable has a significant effect on welfare. This is indicated by the CR value of 2.853, which is greater than the critical value at the significant level of $0.05(5 \%)$, namely 1.998; the probability value of 0.004 is smaller than 0.05 . Based on the results of the analysis, it can be concluded that this study supports the hypothesis which states that business strategy has a significant effect on welfare. The influence of competence on welfare through business strategies. The test results can be seen in Table 3 below:

Table 3

Test Results Influence of competence on welfare through business strategies.

\begin{tabular}{llccc}
\hline & Variable & Direct effect & Indirect effect & Total effect \\
\hline Competence & $\rightarrow$ Strategic & 0.739 & & \\
Competence & $\rightarrow$ Welfare & 0.329 & & \\
Strategic & $\rightarrow$ Welfare & 0.293 & & \\
Competence & $\rightarrow$ Strategic $\rightarrow$ Welfare & 0.216 & $0.739 \times 0.293=0.216$ & 0.546
\end{tabular}

In Table 3, it can be seen that the direct effect of competence on business strategies and business strategies on the welfare of members is 0.739 and 0.293 , respectively. If the total effect is greater than the direct effect, then a variable can be called an intervening variable. Based on the results of the analysis in table, it can be concluded that the results of this study support the hypothesis, which states that competence has a significant effect on the welfare of cooperative members through business strategies.

\section{Discussion}

Competence in this study is formed by indicators of motives, intrinsic factors, self-concept, knowledge, skills, or abilities. These five indicators provide a very varied contribution from the largest to the smallest, while the most considerable contribution is given by the experience indicator, and the smallest contribution is determined by the intellectual ability indicator. This competency variable has a positive and significant effect, either directly or indirectly, on business strategy and welfare. This indicates that competence, which is determined by experience and creativity, will be able to help business actors make the right strategies to improve the welfare of cooperative members. The results of this study support the results of previous studies (Avkiran, 2000; Blašková et al., 2014; Kunjiapu \& Mohamad, 2010; Moghabghab et al., 2016).

A business strategy is a situation that involves the identification and loyalty and commitment of a business actor to the business he is engaged in. In this study, business strategy is measured by product changes, service changes, and distribution changes. The results of the analysis show that respondents appreciate agreeing that service changes are an essential indicator in implementing small-scale business strategies. This indicates that business actors in cooperative members have high enthusiasm because they believe in the consequences for family welfare, so they do their best to continue to provide the best service to consumers. This is consistent with the results of previous research that changes in business strategy, even though on a small scale, have a significant effect on the welfare of cooperative members (Anderson et al., 2010; Jaafar, 2012; Lytle \& Timmerman, 2006; Mmutle \& Shonhe, 2017). In its implementation, this strategy is manifested in changes in service improvements in terms of product availability, the variety of services that consumers want, and the facilitation of consumers to get pleasant benefits. The results of the empirical analysis show that, in general, the respondents in this study responded well to indicators of welfare. This indicates that someone who is part of a cooperative is more effective in increasing welfare than people who do not join the cooperative (Paramata, 2015). This increase in welfare is marked by the rise in family income, although this increase is not significant with an increase in the prices of basic necessities. In addition, health and education improvements are also better than before becoming cooperative members.

The test results through SEM analysis found that competence has a positive and significant effect on welfare. This illustrates that if the actor who is a member of the cooperative wants to improve welfare, he must pay attention to the self-concept indicator. In this case, it does not mean that other indicators are not essential to pay attention to, but because these indicators contribute more than other indicators to the formation of latent variables. The findings of this study support research conducted by previous researchers (Albareda-Tiana et al., 2018; Garzón, 2010; Polnaya et al., 2018), which states that competence has a positive and significant effect on welfare. Based on the analysis, it shows that the business strategy has an effect on the welfare of cooperative members. This indicates that the business strategy that is carried out, even on a small scale, is able to improve the welfare of cooperative members. The findings of this study indicate that changes in products, changes in services, and changes in distribution can promote the welfare of cooperative members.

Changes in service to consumers are the most important part of welfare, especially at the level of sales, which is the primary concern of cooperative member actors (Jack et al., 2006; Kelley et al., 2013; Mubarok et al., 2019). So it can be stated that the strategy is the leading business for cooperative member actors in order to become a guideline for performing professionally so that the welfare of cooperative members can increase. The test results of this study indicate that the business strategies 
carried out by the cooperative members have an effect on welfare. While competence affects business strategy, so the business strategy is able to mediate the influence of competence on the welfare of cooperative members. Increasing the welfare of cooperative members through this business strategy is indicated by changes in services that have a higher loading factor value compared to other indicators. In addition, product change indicators have the second-highest value, followed by distribution change indicators. Competencies possessed by cooperative member business actors will provide knowledge and experience to carry out the right business strategy at the scale of the business they are running.

\section{Conclusion}

The involvement of actors and employers' associations in improving the sustainable welfare of members still needs to be optimized. This is evident from the respondents' perceptions of the empowerment carried out on the human resources of female cooperative members. So it is necessary to optimize the empowerment of business actors. Continuous improvement of the welfare of business members by implementing business strategies still needs to be optimized for all business actors. This can be done by increasing the competence of cooperative members. Based on respondents' perceptions of increasing competence, it still has to be optimized. Competence has a significant effect both on the welfare of members and business strategy, meaning that the welfare of women cooperative business members can be further improved by increasing the competence of business actors. Increasing the competence of business actors will also increase the knowledge and skills of entrepreneurs in making business strategies.

The implementation of a more effective business strategy will be able to improve the sustainable welfare of women cooperative members. In addition, the application of this business strategy is also able to mediate the effect of competence on improving the welfare of female cooperative members. This means that increasing the welfare of female cooperative members will be more effective when the competence of business actors is improved, and then the skills possessed by business actors are applied by practicing business strategies which will further improve the welfare of members of sustainable business actors. The research results reveal that the welfare of women cooperative members can be improved by increasing the competence of business actors. Meanwhile, the business strategy also has a significant effect on improving the welfare of business members in a sustainable manner and is able to mediate the influence of competence on the welfare of business members.

The focus of the business strategy observed in this study is measured from changes in products, changes in services, and changes in distribution, for example, the speed at which organizations anticipate environmental changes. Therefore, it is suggested for future research to further explore the indicators of specific business strategies undertaken by business actors who are members of women cooperatives. From the analysis results it has shown that there was a direct influence of competence on the welfare of business members, but the increase in the welfare of business members would be higher if it were mediated by business strategies. Therefore, it is suggested for business actors that increased competence marked by entrepreneurial motivation, experience, creativity, intellectual abilities and high emotional abilities must be followed by the application of more intensive business strategies. So that the welfare of business members can be continuously improved.

\section{Acknowledgment}

The author would like to thank the Ministry of Research and Technology / National Agency for Research and Innovation, Indonesia, for funding this research in $2019-2020$.

\section{References}

Abu Talib, I. F., Takim, R., Mohammad, M. F., \& Hassan, P. F. (2018). Community Empowerment through Rehabilitation and Reconstruction in Social Sector of Kuala Krai, Kelantan, Malaysia. Procedia Engineering, 212(2017), $294-301$.

Albareda-Tiana, S., Vidal-Raméntol, S., \& Fernández-Morilla, M. (2018). Implementing the sustainable development goals at University level. International Journal of Sustainability in Higher Education, 19(3), 473-497.

An, M., \& Han, S.-L. (2020). Effects of experiential motivation and customer engagement on customer value creation: Analysis of psychological process in the experience-based retail environment. Journal of Business Research, February, $1-9$.

Anderson, A. R., Dodd, S. D., \& Jack, S. (2010). Network practices and entrepreneurial growth. Scandinavian Journal of Management, 26(2), 121-133.

Ataei, P., Karimi, H., Ghadermarzi, H., \& Norouzi, A. (2020). A conceptual model of entrepreneurial competencies and their impacts on rural youth's intention to launch SMEs. Journal of Rural Studies, 75(January), 185-195.

Avkiran, N. (2000). Interpersonal skills and emotional maturity influence entrepreneurial style of bank managers. Personnel Review, 29(5), 654-675.

Bijaoui, I., \& Regev, D. (2015). Entrepreneurship and viral development in rural Western Negev in Israel. Journal of Research in Marketing and Entrepreneurship, 17(1), 54-66.

Blašková, M., Blaško, R., \& Kuchar, A. (2014). Competences and Competence Model of University Teachers. 159, $457-467$.

Boso, N., Cadogan, J. W., \& Story, V. M. (2012). Complementary effect of entrepreneurial and market orientations on export new product success under differing levels of competitive intensity and financial capital. International Business Review, 21(4), 667-681. 
BPS Provinsi Jawa Barat. (2018). Statistik Hotel dan Akomodasi Lainnya Jawa Barat.

Conway, C. (1994). Developing Senior Management Competences at Ocean Group. 7(1), 7-12.

Cuganesan, S., Dunford, R., \& Palmer, I. (2012). Strategic management accounting and strategy practices within a public sector agency. Management Accounting Research, 23(4), 245-260.

Decius, J., \& Schaper, N. (2017). The Competence Management Tool ( CMT ) - A new instrument to manage competences in small and medium-sized manufacturing enterprises. Procedia Manufacturing, 9, 376-383.

Engineer, M., \& Ian King, N. R. (2008). The human development index as a criterion for optimal planning Merwan. Indian Growth and Development Review, 1(2), 172-192.

Finlayson, M., Everard, M., Irvine, K., McInnes, R. J., Middleton, B. A., van Dam, A. A., \& Davidson, N. C. (2018). The Wetland Book: I: Structure and Function, Management, and Methods. The Wetland Book: I: Structure and Function, Management, and Methods, 1-2238.

Garzón, M. D. (2010). A comparison of personal entrepreneurial competences between entrepreneurs and CEOs in service sector. Service Business, 4(3-4), 289-303.

Glogger-frey, I., Herppich, S., Praetorius, A., Natalie, F., Ufer, S., Karst, K., Leutner, D., Behrmann, L., Matthias, B., Karing, C., Klug, J., Hetmanek, A., Ohle, A., Ines, B., Kaiser, J., \& Südkamp, A. (2017). Teachers' assessment competence : Integrating knowledge-, process-, and product-oriented approaches into a competence-oriented.

Hallbäck, J., \& Gabrielsson, P. (2013). Entrepreneurial marketing strategies during the growth of international new ventures originating in small and open economies. International Business Review, 22(6), 1008-1020.

Hampton, A., Cooper, S., \& Mcgowan, P. (2009). Female entrepreneurial networks and networking activity in technologybased ventures: An exploratory study. International Small Business Journal, 27(2), 193-214.

Iglesias, O., Ind, N., \& Schultz, M. (2019). History matters: The role of history in corporate brand strategy. Business Horizons, 63(1), 51-60.

Jaafar, M. (2012). Entrepreneurial marketing and accommodation businesses in East Peninsular Malaysia. Journal of Research in Marketing and Entrepreneurship, 14(2), 164-183.

Jack, S., Hyman, J., \& Osborne, F. (2006). Small entrepreneurial ventures culture, change and the impact on HRM: A critical review. Human Resource Management Review, 16(4), 456-466.

Kelley, D. J., Ali, A., Brush, C., Corbett, A. C., Lyons, T., Majbouri, M., \& Rogoff, E. G. (2013). National Entrepreneurial Assessment for the United States of America.

Kouropalatis, Y., Morgan, R. E., \& Hughes, P. (2012). Pursuing "flexible commitment" as strategic ambidexterity. European Journal of Marketing, 46(10), 1389-1417.

Kunjiapu, S., \& Mohamad, R. (2010). Stepping Up the Ladder : Competence Development through Workplace Learning Among Employees of Small Tourism Enterprises. 7(C), 10-18.

Linton, G., \& Kask, J. (2017). Configurations of entrepreneurial orientation and competitive strategy for high performance. Journal of Business Research, 70, 168-176.

Lytle, R. S., \& Timmerman, J. E. (2006). Service orientation and performance: An organizational perspective. Journal of Services Marketing, 20(2), 136-147.

Mmutle, T., \& Shonhe, L. (2017). Customers' perception of service quality and its impact on reputation in the hospitality industry. African Journal of Hospitality, Tourism and Leisure, 6(3).

Moghabghab, R., Gnc, C., Tong, A., Hallaran, A., \& Anderson, J. (2016). The Difference Between Competency and Competence : A Regulatory Perspective. Journal of Nursing Regulation, 9(2), 54-59.

Mubarok, N., Jannah, S. A., \& Laksanawati, S. (2019). Analisis Identifikasi Masalah Utama Koperasi Di Kabupaten Banyuasin Dalam Mewujudkan Kesejahteraan Anggota. I-ECONOMICS: A Research Journal on Islamic Economics, 4(2), 194-213.

Paramata, S. H. (2015). Peran koperasi Annisa Dalam Meningkatkan Kesejahteraan Anggota di Desa Parungi Kecamatan Boliyohuto Kabupaten Gorontalo. Jurnal Ilmu Administrasi, 4(2), 1-6.

Polnaya, I., Nirwanto, N., \& Triatmanto, B. (2018). The evaluation of lecturer performance through soft skills, organizational culture and compensation on Private University of Ambon. Academy of Strategic Management Journal, 17(2), 1-9.

Syaiful, M. (2016). Kesejahteraan Anggota. Jurnal Progres Ekonomi Pembangunan, 1, 96-110.

Tremblay, E., Hupper, A., \& Waring, T. M. (2019). Cooperatives exhibit greater behavioral cooperation than comparable businesses: Experimental evidence. Journal of Co-Operative Organization and Management, 7(2), 100092.

Wahid, A. R., Hms, U., Wahyuni, S., Studi, P., Ekonomi, P., Pendidikan, J., Keguruan, F., \& Unej, U. J. (2013). Anggota Pada Kpri Ringgit Kecamatan Kendit Kabupaten Situbondo Tahun 2013.

Waweru, N., \& Uliana, E. (2008). Predicting change in management accounting systems: a contingent approach. Problems and Perspectives in Management, 6(2), 72-84. 
(C) 2020 by the authors; licensee Growing Science, Canada. This is an open access article distributed under the terms and conditions of the Creative Commons Attribution (CC-BY) license (http://creativecommons.org/licenses/by/4.0/). 